\title{
Developing Maritime English Materials for Merchant Marine Polytechnic Students Based on Need Analysis
}

\author{
*Agus Sulistiono, Nautical Study Progam, Politeknik Pelayaran Sorong, West Papua, Indonesia, \\ seeme4905@gmail.com \\ Yuniar Ayu Hafita, Nautical Study Progam, Politeknik Pelayaran Sorong, West Papua, Indonesia, \\ y.ayuhafita@gmail.com \\ Ariandy Syamsul Bhahri, Nautical Study Progam, Politeknik Pelayaran Sorong, West Papua, Indonesia, \\ asbrumagesan@gmail.com \\ Wisnu Risianto, Nautical Study Progam, Politeknik Pelayaran Sorong, West Papua, Indonesia, \\ wisnuplap@gmail.com \\ Mustasyfa Thabib Kariadi, Faculty Of Humanities, Jenderal Soedirman University, Purwokerto, Central Java, \\ Indonesia, mtkariadi_pbi@unsoed.ac.id
}

\begin{abstract}
The research aimed to developing Maritime English Materials which are suitable for Deck Students of Makassar Merchant Marine Polytechnic in semester I. The subjects were the seventh semester students and the first semester students. The instruments were questionnaires and interview guideline (in need analysis and evaluation phase). This research was conducted by following Borg and Gall's research design (2003) in combination with jolly and Bollitho's model design (1998) with several modifications. In the first stage, questionnaire and interview guidelines were used to gather the learner's needs. Next, the second stage, the data from need analysis was used to write the course grid. It then was used as guidance in writing the drafts of the developed materials. After being tried out and evaluated, the materials were approved to fulfill the criteria of good materials. Thus, it can be concluded that the developed English reading materials for Makassar Merchant Maritime Polytechnic students are suitable and appropriate with their need and level.
\end{abstract}

Keywords: Research , Development, Need Analysis, Maritime English, Materials Received: 20.11.2020 $\quad$ Accepted: 17.12.2020 $\quad$ Published: 10.01.2021

\section{INTRODUCTION}

To achieve a safe navigation and preserve the environment, ships are equipped according to the International Maritime Organization (IMO) regulations and standards. On the other hand, sea personnel are the people who fulfill these tasks by using the equipment. Therefore, the training of the seafarers for updated information and for better skills also become a very crucial issue.

Communication plays a big role to reduce the accidents for safer navigation and cleaner oceans. The success of achieving better communication among the officers depends on the education and training.

Adequate knowledge of English language to enable the officer to use English publications to perform duties for the deck and engineering officers is the mandatory requirement in Standards of Training, Certification and Watchkeeping (STCW)code in accordance with A-II/1 -2.5 III/1- 2.3 and Code II/1 2 Table a-II/1 A-II/4 for operation and management levels. These requirement are then modeled in IMO Model Course 3.17 (IMC 3.17) Maritime English (ME). It includes the reference materials which guide as a minimum requirement to teach the student nautical terms and some couple of shipboard English phrases including with basic engineering terminology.

Various studies articulated in the papers presented at International Association of Maritime Universities (IAMU) meetings and converences or workshop proceedings, as well as in such projects as Maritime Command (MARCOM), Harmonization of European Maritime Education and Training Schemes (METHAR), Maritime Education and Training Network (METNET) emphasizes the following general features of ME materials. (1) there is rarely a comprehensive, all-inclusive ME textbook or other learning/teaching material (2) no single material (textbook or other) has imposed itself yet as the material with worldwild use or the one setting standards to other ME materials, though one or two have found a wider international use. However, for several decades there has been a demand and a degree of pressure by the international maritime community and the industry to develop (1) Maritime English as a sub-set of English for the exchange of information and transfer of knowledge to be used as a working language in the maritime world (Pritchcard 2004) (2) a restricted variaty of ME as the recommended or in some instances, 
mandatory communication idiom primarily intended for ensuring safety of navigation (e.g SMCP 2001) (Trenkner 1999) (3) standard or more or less widely accepted textbook or other type of material for the learning/teaching of ME (Cole 1999, Logie 2001).

The limited ME materials in Indonesia are becoming a resistance in the process of teaching and learning to achieve the goals in IMO. The use of irrelevant ME is a problem in the implementation of IMO. It will also cause a bad effect to the learners. Some of them will be less motivated to learn English and have limited number of technical vocabularies related to their major. Then, they will find it difficult when they are on board in the future. In a long run, it will affect to their performance and safety onboard.

The ME materials based on the IMC 3.17 in Indonesia are limited. The availability of those materials which are suitable for Indonesian learners are rarely found in the market so that the lecturers must find out or even create themselves.

In the rest of this study, the writer would like to suggest a model of ME Materials for deck students of MMMP in the first semester.

1) English for Specific Purpose

Definition of ESP by Dudley-Evans \& St. John in Mike Brunton (2009) is by the absolute characteristics and variable characteristics. The absolute characteristics include;

a. ESP is defined to meet specific needs of the learners

b. ESP makes use of underlying methodology and activities of the discipline it serves,

c. ESP is centred on the language appropriate to these activities in terms of grammar, lexis, register, study skills, discourse and genre.

Then, variable characteristics of ESP are

a. ESP may be related to or designed for specific disciplines,

b. ESP may use, in specific teaching situations, a different methodology from that of General English,

c. ESP is likely to be designed for adult learners, either at a tertiary level institution or in a professional work situation. It could, however, be for learners at secondary school level,

d. ESP is generally designed for intermediate or advanced students,

e. Most ESP courses assume some basic knowledge of the language systems.

Belcher $(2006,135)$, states that 'ESP assumes that the problems are unique to specific learners in specific contexts and thus must be carefully delineated and addressed with tailored to fit instruction.' Mohan $(1986,15)$ adds that ESP courses focus on preparing learners 'for chosen communicative environments.' Learner purpose is also stated by Graham \& Beardsley (1986) and learning centeredness (Carter, 1983; Hutchinson \& Waters, 1987) as integral parts of ESP. Lorenzo $(2005,1)$ reminds us that ESP 'concentrates more on language in context than on teaching grammar and language structures.' He also points out that as ESP is usually delivered to adult students, frequently in a work related setting (EOP), that motivation to learn is higher than in usual ESL (English as a Second Language) contexts. Carter (1983) believed that self-direction is important in the sense that an ESP course is concerned with turning learners into users of the language.

2) Need Analysis in ESP

The type of needs analysis for ESP focuses on gathering detailed language used for vocational or other specific language needs (Martin, 2003). Needs analysis is the foremost and an integral part of the materials development processes as claimed by Montazeri and Hamidi (2013) including English for academic and specific purposes. Dudley-Evans and Johnson (1998) assert that ESP takes a better care of students' needs and extends beyond its traditional EAP base. However they contend that there is the need for more research regarding the nature of written or spoken discourse that must be carried out by the ones who are enrolled in ESP courses. They further draw attention to the fact that other disciplines are beginning to the draw upon insights ESP related research. According to Phan (2005), during the 1970s, needs analysis procedures made their appearance in language planning and became widespread in language teaching. In their first days, such procedures were used as the initial process for the specification of behavioural objectives which then explored different syllabus elements, such as functions, notions, lexis, in a more detailed manner. "At the same time, Language for Specific Purposes (LSP) became a matter of general interest and LSP experts were making efforts to give birth to a more comprehensive and better LSP syllabus. As a result, needs analysis was warmly welcomed by LSP teachers as an approach to course design, which focused on learner's needs" (Nunan,1988).

Based on Richards et al. (1992), in language teaching, needs analysis is the process of determining the needs for which a learner or group of learners requires a language and arranging the needs according to priorities. Therefore, in developing ESP materials, needs assessment makes use of both 
subjective and objective information (e.g. data from questionnaires, tests, interviews, observation) and seeks to obtain information on:

a. The situations in which a language will be used (including who it will be used with)

b. The objectives and purpose for which the language is needed.

c. The types of communication that will be used (e.g. written, spoken, formal, informal)

d. The level of proficiency that will be required

Need assessment is a part of curriculum development and is normally required before a syllabus can be developed for language teaching. According to Nation and McAlister (2010), English for specific purposes course has been taught for many years. Many of the suggestions regarding needs analysis are applicable for the design of an ESP course within a particular context. When more generic courses are being designed, or when information is not available locally, we could also look at publicly available corpora, especially specialized corpora, for language needs analysis purposes. These may become an increasingly valuable tool as more and more corpora become available and search engines become more powerful and more user-friendly.

3) IMO Model Course 3.17

The programme of model training courses developed out of suggestions from a number of IMO Member Governments, following the adoption of the International Convention on Standards of Training, Certification and Watchkeeping for Seafarers, (STCW), 1978, as amended. Assisted by contributions from various Governments, IMO has designed the series of courses to help implement this Convention and, further, to facilitate access to the knowledge and skills demanded by increasingly sophisticated maritime technology. The courses are flexible in application: maritime institutes and their teaching staff can use them in organizing and introducing new courses or in enhancing, updating or supplementing existing training material.

The model courses each include a course framework (detailing the scope, objective, entry standards, and other information about the course), a course outline (timetable), a detailed teaching syllabus (including the learning objectives that should have been achieved when the course has been completed by students), and guidance notes for the instructor and a summary of how students should be evaluated.

In reference to the IMO model course for Maritime English, colleges and training institutions should note that this course more than fulfils the competences regarding English language contained in the STCW Convention, 1978, as amended. Today, trainers of English for Specific Purposes hold that a broad understanding of English is required in order to meet specific objectives. This rationale underpins the IMO model course for Maritime English, however, administrations may decide to adopt an alternative approach. The course is intended to provide a guideline to assist administrations develop their own training programmes to achieve the standards for English set out in the STCW Convention, 1978, as amended. Model courses related to the STCW Convention were revised and updated after the major revision of the Convention in 1995. Consequent to the adoption of the Manila Amendments in 2010 to the STCW Convention and Code, some of the model courses related to the STCW Convention and Code are being revised and updated.

Because educational systems and the cultural backgrounds of trainees in maritime subjects vary considerably from country to country, the model course material has been designed to identify the basic entry requirements and the trainee target group in universally applicable terms. In order to meet the requirements and recommendations of the STCW Convention, 1978, as amended, both the language and the maritime content of this model course are clearly set out, along with the levels of language knowledge and language communication skills.

4) Learning Materials Design

According to Corbel (1985 in Nunan, 1991:219), materials are designed through a four stage procedure: a) identifying the learners areas of interest in broad thematic terms, b) identifying a series of communication situations related to that theme and linking them to form an action sequence, c) selecting or devising materials which are appropriate to the action sequence and d) choosing language points to focus on form the materials.

Jolly and Bolitho in Tomlison (1998: 96-100) summarize the steps that most material writers use to design the materials into seven steps. Here are the brief explanations of each step proposed by Jolly and Bollitho (Tomlison, 1998:96-100):

a. Identification of need for materials

b. Exploration of need

c. Contextual

d. Pedagogical realization of the materials.

e. Production of the materials 
f. Students use of material

g. Evaluation of the materials against agreed objectives

5) Learning Material Evaluation

Evaluating learning materials effectively is a very important process for all EFL teachers and material developers. Tomlinson and Masuhara (2004:1) define material evaluation as a process of measuring the value (or potential value) of a set of learning materials by making judgments about the effect of the materials on the people using them. The material evaluation tries to measure for example; a) the appeal of the materials to the learners, b) the validity of the materials, c) the ability of the materials to interest the learners and the teachers, d) the ability of the materials to motivate the learners, e) the potential value of the materials, f) the assistance given to the teachers in terms of the preparation, delivery, and assessment, and g) the flexibility of the materials.

They also classify the material evaluation into three types. They are Pre- Use Evaluation, whilst- Use Evaluation, and Post-Use evaluation. Here are the brief descriptions of each type.

a. Pre-Use Evaluation. It concerns on making predictions about the possible value of the materials for their users. It is frequently general, subjective, and unreliable because it is writer's judgment on the designed materials based on his or her belief toward the designed materials not based on fact in the classroom use.

b. Whilst- Use Evaluation. It is an evaluation which is used to measure the value of materials whilst using them or whilst observing them being used. This kind of evaluation is more objective and realistic rather than pre- use evaluation because it makes use of measurement of the obtained data rather than prediction on the effect of the materials before using them. However, this evaluation is limited to measuring what is observable. Here are points that can be measured in this evaluation: clarity of instruction, clarity of layout, comprehensibility of texts, achievability of tasks, flexibility of the materials, appeal of the materials, and motivating power of the materials.

c. Post - Use Evaluation. It is the most worthwhile type of evaluation because it can gauge the actual effect of the materials being evaluated on the users. It can gauge short term effects as durable learning and application. Tomlinson and Masuhara (2004:5) suggest several points that the material evaluation should discover as follows- learners' improvement on performance and understanding after using the materials, learners' problems and difficulties during the implementation of the materials, and the meet of the materials toward learners' need.

\section{METHODS}

\section{Type of Study}

Wallace (2006:114) defines that Research and Development is a strategy that incorporates extant knowledge from theory and empirical research into a product that can be used for the improvement of practice. As the goal of the study is to develop an educational product of Maritime English Materials, this research study is classified into Research and Development category.

The steps of the process in R\&D refer to Borg (1983:775) cycle which consist of ten steps. The first is research and information collection. The second is planning. The third is developing preliminary product. The fourth is preliminary field testing. The fifth is operational testing. The sixth is operational product revision. The seventh is main field testing. The eight is main product revision. The ninth is final product revision. The last is dissemination and implementation report on product at professional seminar.

The modification design of Borg and Ghall's design and Jolly and Bollitho's design that is applied in this study is as follows.

a. Conducting Need Analysis.

b. Developing Course Grid.

c. Organizing or Writing the Materials/Contextual and Pedagogical realization.

d. Judging the Designed Materials by Using Expert Judgment.

e. Trying out the Second Draft.

\section{Setting and Subject of the Research}

This research was conducted at Merchant Marine Polytechnic of Makassar.The subject of this research were deck students at 7 th and 1 st semester and the ME lecturers as respondents. There were 79 deck students in the seventh semester participating in the need analysis. There were 30 students in the first semester participating in the try-out of the developed materials. There were $6 \mathrm{ME}$ lecturers participating in interview and materials evaluation. The researcher applied purposive sampling technique in gathering information from respondents. 


\section{Instrument}

There are two important points to be considered in developing the Maritime English reading materials. They are obtaining the learners needs and evaluating the developed materials. The data from those points were collected through questionnaire and also interview guidelines.

\section{Data Collection technique}

To collect the data needed in this study, a multi method of data collection is used. This multi method approach is known as triangulation (Bell, 2005:116).

There are two instruments which are used in this research. They are questionnaires and interview guidelines. The data of the research was collected in two separated times. The first one is collecting the data of the learner's profiles and their needs in learning ME. It is done at the early stage of the research through the first questionnaire and the first interview guidelines. The first questionnaire is distributed to the students and then the interview guidelines are only asked to the ME Lecturers.

The second one is collecting the data about the evaluation of the developed materials which is done during and after the try outs of the materials. The data is obtained by noting down the field notes of the teaching and learning process during the try outs of the materials, distributing the second questionnaire to the students, the ME Lecturer and interviewing students by using the second interview guidelines.

\section{Data Analysis Technique}

As the data of this research is derived by using two instruments, thus there are two data analysis technique, descriptive statistic and explication technique.

As the purpose of the questionnaire is to discover the learner's profiles and their needs of ME materials, the researcher analysed the first questionnaire by percentage. Here, the frequency is divided by the total of the respondents and the result is multiplied by 100\% (Sudjana, 2001:129). The formula is as follows:

$$
\begin{aligned}
& \text { Percentage }(\%)=\frac{f}{N}(100) \\
& \text { Where } \\
& \text { P : Percentage } \\
& \text { f : : Frequency } \\
& \mathrm{N} \quad: \quad \text { Total of Respondents } \\
& \text { 100\% : Fixed Number }
\end{aligned}
$$

For the second questionnaire, the researcher used descriptive statistics in analysing the data. To obtain the data, the researcher used a Likert scale with forced choice method by removing the neutral option. Each response to the statement is scored. The score are four strongly agree, three for agree, two for disagree and one for strongly disagree.

To analyse the statistic data derived from the second questionnaire, the researcher used Central Tendency Measurement that consist of mean, median, and mode. It is used to talk about central point in the scores distribution of the data and variability (standard deviation) to measure whether the data is homogenous or not (Hatch and Farhady, 1982:54). Ideal mean (Mi) and ideal standard deviation (SDi) are also used to converse the data (Sudijono, 2003:339) The computation of both ideal mean and ideal standard deviation of this research are:

$$
\begin{aligned}
& \text { 1. } \mathrm{Mi}=\frac{1}{2}(\text { Maximum score }+ \text { minimum score }) \\
& =\frac{1}{2}(4+1) \\
& \begin{aligned}
& =2.5 \\
\text { 2. } \mathrm{SDi} & =\frac{1}{6}(\text { Maximum score }- \text { minimum score })
\end{aligned} \\
& =\frac{1}{6}(4+1) \\
& =0.5
\end{aligned}
$$

After being analysed, the data is then categorized into five grades. They are very poor, poor, fair, good and very good. This categorization follows Sudijono's quantitative data conversion as shown in the following table. 
Table 1. Quantitative Data Conversion Adapted from Sudjono (2003:339)

\begin{tabular}{|l|l|l|l|}
\hline No. & Score Range Formula & Score Range & Category \\
\hline 1. & $\overline{\mathrm{X}}>\mathrm{Mi}+1.5 \mathrm{SDi}$ & $\overline{\mathrm{X}}>3.25$ & Very good \\
\hline 2. & $\mathrm{Mi}+0.5 \mathrm{SDi}<\overline{\mathrm{X}} \leq \mathrm{Mi}+1.5 \mathrm{SDi}$ & $2.75<\overline{\mathrm{X}} \leq 3.25$ & Good \\
\hline 3. & $\mathrm{Mi}-0.5 \mathrm{SDi}<\overline{\mathrm{X}} \leq \mathrm{Mi}+1.5 \mathrm{SDi}$ & $2.25<\overline{\mathrm{X}} \leq 2.75$ & Fair \\
\hline 4. & $\mathrm{Mi}-1.5 \mathrm{SDi}<\overline{\mathrm{X}} \leq \mathrm{Mi}-0.5 \mathrm{SDi}$ & $1.75<\overline{\mathrm{X}} \leq 2.25$ & Poor \\
\hline 5. & $\overline{\mathrm{X}}>\mathrm{Mi}-1.5 \mathrm{SDi}$ & $\overline{\mathrm{X}} \leq 1.75$ & Very Poor \\
\hline
\end{tabular}

\begin{tabular}{lll}
\multicolumn{2}{c}{ Where: } & \\
$\overline{\mathrm{X}}$ & $=$ & the average mean \\
$\mathrm{Mi}$ & $=$ & the ideal mean \\
$\mathrm{SDi}$ & $=$ & the standard deviation
\end{tabular}

With respect to the data derived from interview guidelines, explicitation technique is employed. This explicitation technique has five steps or phases as follows.

a. Bracketing and phenomenological reduction.

b. Delineating units of meaning

c. Clustering of units of meaning to form themes

d. Summarising each interview, validating and where necessary modifying it

e. Extracting general and unique themes from all the interviews and making a composite summary (Groenewald in Wallace:2006)

1) Research Procedure

As the research study is categorized into $\mathrm{R} \& \mathrm{D}$, the research procedure follow a model by Borg and Gall (1983:775). Due to the limitation of time and budget, some cycle of Borg and Ghall's designed would be eliminated. This research only applied the first, third, sixth, ninth and tenth cycles of Borg and Gall's designed. In addition, since Borg and Ghall's designed is not contextual to language and learning context, it was combined with Jolly's and Bollitho's Material Designed (Tomlison, 1998:95) with several modifications on them.

The modification design of Borg and Ghall's design and Jolly and Bollitho's design that is applied in this study is as follows.

a. Conducting Need Analysis

b. Developing Course Grid.

c. Organizing or Writing the Materials/Contextual and Pedagogical realization.

d. Judging the Designed Materials by Using Expert Judgment.

e. Trying out the Second Draft.

f. Evaluating the Materials.

2) Writing the Final Draft. Validity and Reliability

According to Charles (1998:42) validity in research data refers to whether the data give a description of the topic being studied. In addition, in the same tone, Bell (2005:117) says that validity tells us whether an item or instrument measures or describes what it is supposed to measure or to describe. To validate the data collected in this research the researcher used content validity.

Besides being valid, research data also should be reliable. Thus, to make sure that the research data which derive from the second questionnaire. It used SPSS 16 and employed Alpha Cronbach Formula. The description of Internal Consistency of Cronbach's Alpha Value.

\section{RESULTS}

According to the observation that was done in the early stage of this research study, it was found that students of MMMP needed ME materials which focused on vocabularies, pronunciation, grammar, and text task. Therefore, the design units, English reading materials, were based on the result of the needs analysis as well as interview and based on the curriculum used in MMMP.

The data obtained from the need analysis then were used as the basis of designing the units in forms of Maritime English reading materials for students of MMMP. Due to the fact that the students needed to learn general English not only to fulfill the IMC 3.17 but also to support their background study - MMMP, the principles of ESP (Hutchinson and Waters, 2006; Richards, 2001) and material development (Jolly and Bollitho, 1998) were applied to design the materials that were appropriate to the students' needs. 
There are four basic knowledge, understanding and proficiency that were further developed in four units. Every unit consists of various tasks. They are divided into three focuses; vocabulary, text type, and grammar. The difference lies on the input texts given in every unit. These tasks were graded by using Procedural Factors proposed by Nunan (2004: 122) and sequenced by using ESA Patchwork Sequence proposed by Harmer (1998:25-30). The variety of the tasks in the developed materials is based on task typology proposed by Pattison (1987 in Nunan, 2004: 57) and reading skill typology proposed by Grellet (1981 in Nunan, 2004: 61).

The developed English reading materials used seven reading texts which were spread into four units; two texts for unit one, two texts for unit two, one text for unit three and two texts for unit four. The texts in unit two are classified into aesthetic reading, while the texts in unit one and three are classified into efferent reading (Rosenblat in Tompkins and Hokisson, 1995: 198-199).

The developed English reading materials met one of three roles of materials pointed by Rihard and Rogers in Nunan (1991: 213). The role is focusing on understandable, relevant, and interesting exchanges of information, rather than presentation of grammatical form.

The first draft of the developed materials then was consulted to the expert of material development. To avoid the subjective judgment. It was obtained that most of the aspects were very good and ready to be tried out. To support the expert judgment on the developed materials, a form of questionnaires was also administered to the English lecturers, English tutors, and English education students by using five aspects of evaluation. This evaluation was classified as pre-use evaluation (Tomlinson and Masuhara, 2001: 3).

A pre-use evaluation needed a support from empirical data obtained from while-use evaluation (Tomlinson and Masuhara, 2001: 4). To hold a while- use evaluation, a try out- out of developed materials to the students was conducted. During the try-out, two filed notes were noted by the researcher as evidences and support data for this research.

After conducting the try-out, a form of empirical evaluation questionnaire which consisted of eighteen statements was distributed to the students in order to measure the actual effect of the tried-out materials on the students. Five components of the developed materials were evaluated by using theories proposed by Nunan (2000), Tomlinson and Masuhara (2004), and McDonough (2003).

The data obtained from such evaluations then were analyzed. Considering respondents' opinion on the developed and tried-out materials that have been mentioned under previous section, the researcher revised the designed materials as shown in the table

\section{DISCUSSION AND CONCLUSIONS}

The procedure of this research refers to the theories of Research and Development proposed by Borg and Gall in combination with theories of material development proposed by Jolly and Bollitho. The development of Maritime English materials for students of MMMP consists of seven phases, i.e.conducting need analysis, developing material grid, organizing or writing the materials, judging the designed materials by using expert judgment, trying out the second draft, evaluating and revising the materials, and writing the final draft of the designed materials.

The developed ME materials consist of four units. They focus on vocabulary, reading task, and grammar. All of them are integrated each other by using two input texts. The first input text focuses on vocabulary development; the second input focuses on task, while the last focus, grammar focus, covers all of grammar points covered in both aforementioned input texts.

All of the tasks designed in these materials followed Patchwork Sequence of ESA proposed by Harmer (2003). Before coming to the first task, the students are introduced with an introductory paragraph related to text they will deal with. A series of pictures which depict the theme of the text accompany the introductory paragraph. This introductory paragraph stimulates the students to be aware of the text which will come later. It raises students' curiosity toward the text that will be studied.

\section{REFERENCES}

Belcher, D. (2006). English for specific purposes: Teaching to perceived needs and imagined futures in worlds of work, study and everyday life. TESOL Quarterly, 40(1), 133-156.

Bell, Judith. 2005. Doing Your Research Project. New York: Open University Press

Borg, W.R., \& Gall, M.D. 1983. Educational Research: An Introduction, 7th Edition. New York: Longman, Inc. Brunton, Mike (2009). An account of ESP - with possible future directions). English for Specific Purposes Issue 3 (24), Volume 8, 2009 (http://www.esp-world.info)

Carter, D. (1983). Some propositions about ESP. The ESP Journal, 2, 131-137. 
Charles, C.M. 1998. Introduction to Educational Research, 3rd Edition. New York: Longman.

Cole, C. W. (1999). The impact of multicultural and multilingual crews on MARitime COMmunication - What is (y)our position? Pomorstvo Maritime Affairs 13, 115-123. Rijeka, Croatia.

Dudley-Evans, T. \& St. John, M.J. (1998). Developments in ESP: A multidisciplinary Approach. Cambridge: Cambridge University Press.

Gall, Meridith D. 2003. Educational Research; An Introduction. Boston: Pearson Education Inc.

Graham, J. G. \& Beardsley, R. S. (1986). English for specific purposes: Content Language, and communication in a pharmacy course model. TESOL Quarterly, 20(2), 227-245.

Hatch, Evelyn and Hossein Farhady. 1982. Research Design and Statistics for Applied Linguistics. Massachusetts: Newbury House Publisher.

Hutchinson, T \& Waters, A. (1987). English for specific Purpose (A learning-Centred Approach). Cambrigde University press.

IMO, 1995. International Convention on Standards of Training, Certification and Wacthkeeping for Seafarers 1978 as amended in 1995 (STCW Convention), International Maritime Organisation, London.

Jolly, D., \& Bolitho, R. (1998). A framework for materials writing. In B. Tomlinson (Ed.), Materialsdevelopment in language teaching (pp.107-134). Cambridge, U.K: Cambridge University Press.

Keputusan Kepala Badan Pengembangan Sumber Daya Manusia Perhubungan No. PK.02/BPSDMP-2013 tanggal 1 Juli 2013 tentang Kurikulum Pembentukan Kompetensi Kepelautan

Logie, C. (2001). Thinking globally, acting locally - implementation of IMO Model Course 3.17: Maritime English. Paper presented at the Eleventh IMLA international Workshop on Maritime English (WOME 11), Varna, Bulgaria.

Lorenzo, F. (2005). Teaching English for Specific Purposes (ESP). Retrieved from http://www.usingenglish.com/teachers/articles/teaching-english-for-specific-purposes-sp.html

Martin, B. (2003): Assessing Students' Language Needs in a Needs Analysis. Retrieved June 20, 2013 from http://www.paaljapan.org/resources/PAL9/pdf/ BalintMartin.pdf

Mohan, B. A. (1986). Language and content. Reading, MA, Addison-Wesley.

Montazeri, M., \& Hamidi, H. (2013). A closer look at different dimensions of needs analysis in the field of ELT. ELT Voices- India, 3 (1), 104-111.

Nation, I. S. P., \& Macalister, J. (2010). Language Curriculum Design. NY:Routledge

Nunan, D. (1991). Language teaching methodology: A textbook for teachers. London: Prentice Hall. , David. 2004. Task-based Language Teaching. New York: Cambridge University Press

Phan, H. L. (2005): Munby's needs analysis model and ESP. Retrieved June 20, 2013 from http://www.asian-efl-journal.com/pta_october_07_plh.php.

Prithcard B. (2004). A Survey of Maritime English Materials. [Online] 2009. [Cited: June 14, 2014.] www.pfri.uniri.hr/.../Pritchard_Erasmus_English5.pdf

Richards, J. C., Platt, J., \& Platt, H. (1992): Dictionary of Language Teaching and Applied Linguistics.UK: Longman Publishing Group.

STCW.7/Circ.11 Interim guidance to STCW Parties on the application of the standard marine communications phrases (SMCP) as required by section A-II of the STCW Code.

Sudijono, Anas. 2003. Pengantar Evaluasi Pendidikan. Jakarta: PT. Raja Grafindo Persada.

Tomlinson, Brian. 1998. Materials Development in Language Teaching. Cambridge: Cambridge University Press

Tomlinson, Brian and Masuhara, Hitomi. 2004. Developing Language Course Materials. Singapore: RELC

Trenkner, P. (1999). The IMO - Standard Marine Communication Phrases - state of affairs and status in MET. Pomorstvo Maritime Affairs 13, 125-140. Rijeka, Croatia.

Wallace, Mike., and Louise Poulson. 2006. Learning to Read Critically in Educational Leadership and Management. London: Sage Production 